\title{
Primary and secondary modeling of Brochothrix thermosphacta growth under different temperature and $\mathrm{ph}$ values
}

\author{
Leticia Dias dos Anjos GONÇALVES ${ }^{1 *}$, Roberta Hilsdorf PICCOLI², Alexandre de Paula PERES², \\ André Vital SAÚDE 3
}

\begin{abstract}
Bochothrix thermosphacta is an optional aerobic psychrotrophic related to the meat deterioration and consequently loss of a refrigerated cargo contaminated. Predictive microbiology can be used as a quality assurance tool, since it allows the prediction of microbial response based in pass observations. This work aimed model the growth of $B$. thermosphacta under variation of $\mathrm{pH}$ and temperature. For this purpose, the experimental growth data were fitted to the primary models of Baranyi and Roberts and the modified Gompertz model and the data for the maximum rate of growth ( $\mu$ max) were adjusted to Ratkowsky extended secondary model. The results showed us that the influence of temperature on growth parameters was more evident than $\mathrm{pH}$. Since, by fixing the temperature the change of $\mathrm{pH}$ little altered the $\mu$ max. However, as the temperature rises the elevation at the $\mu$ max is considerable, for example the comparison of predicted values for $\mu \max$, when the temperature exceeds $4{ }^{\circ} \mathrm{C}$ to $12{ }^{\circ} \mathrm{C}$, it is clear that these rates are more than double. Finally, it is emphasized that all tested models feature good fit to the experimental data, which makes them validated for prediction growth of $B$. thermosphacta in the same conditions tested experimentally.
\end{abstract}

Keywords: deterioration; refrigeration; predictive models.

Pratical Application: To predict the growth of B. thermosphacta under varying temperature and $\mathrm{pH}$ conditions.

\section{Introduction}

Generally, bacteria are absent or present in very low levels in muscle tissues from healthy animals. This is due to the inherent protective barriers (skins, leather) and the natural mechanisms of antimicrobial defense (lysozyme, antimicrobial peptides) of the living animal, which are destroyed at slaughter, so that the resulting meat become exposed to increasing levels of contaminants (Nychas et al., 2008). This fact leads in decreased in shelf- life of the meat, which is dependent on the number and type of contamination present initially and during storage conditions, especially temperature, $\mathrm{pH}$, gas atmosphere (Russo et al., 2006).

With regard to $\mathrm{pH}$, foods of low acidity $(\mathrm{pH}>4.5)$, such as meat whose $\mathrm{pH}$ can range from 5.5 to 7.0 (Cárdenas et al., 2008), are more subject to microbial multiplication, both of pathogenic and deterioration species (Franco \& Landgraf, 2005). An example of the effect of $\mathrm{pH}$ on meat microbial kinetics can be seen with work by Koutsoumanis et al. (2006), were able to observe the significant effect of ground meat $\mathrm{pH}$ (5.34 and 6.13) on a growth kinetics of Pseudomonas, B. thermosphacta and bacteria of the family Enterobacteriaceae, was observed, for example, for $B$. thermosphacta at $10^{\circ} \mathrm{C}$ the growth rate doubles as the $\mathrm{pH}$ goes from 5.4 to 6.1 .

Various conservation methods can be used to increase the shelf life of fresh meat, including refrigeration (Ercolini et al., 2009). The use of cold temperatures, is considered the most effective method of retarding or inhibiting microbial growth in meat products during transportation or storage, besides maintaining product quality and extending shelf life (Al-Jasser, 2012). Therefore, it is extremely important to control and maintain the refrigeration temperature within the acceptable limits to ensure the security and integrity (Zhou et al., 2009).

However, is related in chill-stored meat the development of organoleptic spoilage to microbial consumption of meat nutrients, such as sugars and free amino acids and the release of undesired volatile metabolites. These activities may be performed at low temperatures by psychrotrophic bacteria, compromising the sole effect of temperature as affecting preservation (Ercolini et al., 2009). They can grow at low temperatures, modifying their cytoplasmic membrane and increasing the unsaturated fatty acids levels, which keep this membrane in semifluid state, thereby facilitating the transport of nutrients and enzymes (Madigan et al., 2010). The ability of these microorganisms to grow at low temperatures is one of the challenges to the meat industry in relation to meat quality and public health control (Hernández-Macedo et al., 2011).

This decomposition is largely caused by psychrotrophic species Brochothrix thermosphacta which represents a significant component of microbial deterioration of meat. For this micro-organism, the meat is a growth medium which can do it both aerobically 
and in anaerobic conditions, producing strong odors (Pin et al., 2002) associated with the production of acetoin, diacetyl and 3-methylbutanol (Dainty \& Mackey, 1992).

A recent study by Nowak \& Piotrowska (2012) on the microbial degradation of $B$. thermosphacta in meat and meat products, showed that different strains produce different hydrolases which degrade meat. Some strains are capable of degrading protein, or even produce proteases with different substrate specificities. Casaburi et al. (2014) studied the activity of many strains of B. thermosphacta in meat reported that almost all were able to grow in the presence of sarcoplasmic extract with glucose and produce histamine, which is used as a quality assessment criterion.

To assess the quality of the meat during storage or refrigerated transportation, if it was initially contaminated with $B$. thermosphacta, we can use the predictive microbiology. This tool aims to provide reliable models for microbial behavior simulations in food products (Couvert et al., 2010). Therefore, the use of predictive models can have a very effective application in the food industry, providing reliable predictions able to prevent risks to consumer health in addition to making the process economically viable, by diminishing losses and helping in decision-making (Juneja et al., 2003).

This work was done in order to model and validate mathematical models that describe the growth of Brochothrix thermosphacta at different temperatures and $\mathrm{pH}$.

\section{Materials and methods}

\subsection{Standardization and maintenance of the inoculum}

The lyophilised bacteria Brochothrix thermosphacta ATCC 11509 was used in the experiment and it was stored in freezing media ( $15 \mathrm{~mL}$ of glycerol, $0.5 \mathrm{~g}$ bacteriological peptone, $0.3 \mathrm{~g}$ yeast extract, $0.5 \mathrm{~g} \mathrm{NaCl}$ and $100 \mathrm{~mL}$ of distilled water) in freezer at $-18^{\circ} \mathrm{C}$.

To use the strains, they were activated into BHI broth and incubated at $28^{\circ} \mathrm{C} / 24 \mathrm{~h}$ to obtain the number of cells necessary for standardization.

\subsection{Effect of storage temperature and $p H$ of the medium on growth of $B$. thermosphacta in meat broth}

Suitable aliquots of standard inoculum were transferred to $100 \mathrm{~mL}$ of meat broth $(10 \mathrm{~g}$ meat extract, $10 \mathrm{~g}$ peptone, meat, $5 \mathrm{~g}$ tryptone and $5 \mathrm{~g}$ glucose $/ 1 \mathrm{~L}$ ) at a final concentration of $10^{4} \mathrm{CFU} / \mathrm{mL}$ and incubated at temperatures of $4{ }^{\circ} \mathrm{C}, 7^{\circ} \mathrm{C}$ and $12{ }^{\circ} \mathrm{C}$. The $\mathrm{pH}$ of culture medium was initially adjusted to $5.5 ; 6.0$ and 6.3 with $2 \mathrm{M} \mathrm{NaOH}$ and $2 \mathrm{M} \mathrm{HCl}$ at $\mathrm{pH}$ meter (model Digimed DM20).

The growth of $B$. thermosphacta in each $\mathrm{pH}$ and temperature was monitored at these times: 3 hours, 6 hours, 9 hours, 12 hours, 24 hours, 30 hours, 36 hours, 48 hours, 54 hours, 60 hours, 72 hours, 84 hours, 96 hours, 108 hours and 120 hours, in which $1 \mathrm{~mL}$ of aliquot was collected and transferred to tubes containing $9 \mathrm{~mL}$ of $0.1 \%$ peptone water, performing serial dilutions. Aliquots of $0.01 \mathrm{~mL}$ of appropriate dilutions were incubated on plates containing TSA, by using the technique of the microdrop. The plates were incubated at $28^{\circ} \mathrm{C} / 24$ hours, and then had their colonies quantified.

\subsection{Analysis of growth data for obtaining models}

In the first stage, the maximum specific growth rate $\left(\mu_{\mathrm{m}}\right)$, and the lag phase $(\lambda)$ were calculated for each experimental combination. Growth parameters were obtained by the modified Gompertz and Baranyi and Roberts equation to the experimental data through DMFit 3.0 program. In the second stage, the estimates obtained for $\mu$ max were adjusted for the extended Ratkowsky model to determine the effect of temperature and $\mathrm{pH}$ on the maximum specific growth rate of B. thermosphacta, according to the following Equation 1:

$\mu_{\max }=a\left(p H-p H_{\text {mim }}\right)\left(T-T_{\text {mim }}\right)^{2}$

where a is the regression constant, and $\mathrm{pHmim}$, Tmim are respectively the minimum $\mathrm{pH}$ and minimum temperature theoretically estimated for microorganism growth.

\subsection{Validation of the results by statistical analysis of models}

The following statistical parameters were calculated for validation of the models: correlation coefficient $\left(\mathrm{R}^{2}\right)$, mean square error (RMSE), bias factor and accuracy factor (Samapundo et al., 2005). The correlation coefficient $\left(\mathrm{R}^{2}\right)$ describes the model fit throughout the length of the curve; the closer the value $\mathrm{R}^{2}$ is to one, the better the model fit is.

The mean square error (RMSE) is given by Equation 2, and presents the model error relative to the data, that is, how the predicted values are close to the observed values; the closer to zero, the better the fit is.

$R M S E=\frac{S Q R}{n}=\sum\left(\text { value }_{\text {obs }}-\text { value }_{\text {pred }}\right)^{2}$

where, value ${ }_{\text {obs }}$ is the experimental value, value $e_{\text {pred }}$ is the value predicted by the model, SQR is the sum of square residuals, and $\mathrm{n}$ is the number of degrees of freedom (number of data points - number of model parameters).

The bias factor shown in Equation 3 gives the same weight in the average values that overestimates and underestimates the average, that is, an average relative deviation.

Bias factor $=10^{\sum \log \left[\left(\text { value }_{\text {obs }}-\text { value }_{\text {pred }}\right) / n\right]}$

where, value ${ }_{\text {obs }}$ is the experimental value, value $e_{\text {pred }}$ is the value predicted by the model, and $\mathrm{n}$ is the number of data points minus the number of model parameters.

The accuracy factor is the most reliable and accurate statistical measurement because it uses both the predicted and observed values, assessing the percentage prediction error. This factor takes into account only the absolute values. The closer the value is to 1 , the lower the percentage error is. The calculation factor was corrected by Equation 4 .

Accuracy factor $=10^{\sum \mid \log \left(\text { value }_{\text {obs }}-\text { value }_{\text {pred }}\right) \mid} / n$

where, value $_{\text {obs }}$ is the experimental value; value $e_{\text {pred }}$ is the value predicted by the model, and $n$ is the number of data points minus the number of model parameters. 


\section{Results and discussion}

\subsection{Primary growth model of Brochothrix thermosphacta in meat broth}

Table 1 shows the growth parameters for $B$. thermosphacta at three different temperatures and $\mathrm{pH}$ values.

Table 2 shows the coefficient of determination $\left(\mathrm{R}^{2}\right)$ and the root mean square error (RMSE) for the primary models.

The equations of Baranyi and Roberts and the modified Gompertz models for growth conditions of $B$. thermosphacta at $4^{\circ} \mathrm{C}, 7^{\circ} \mathrm{C}$ and $12^{\circ} \mathrm{C}$ at pH 5.5; 6.0 and 6.3 , are shown in Table 3 .

For the analysis of data shown in Table 1 note that the lag phase estimated by the Baranyi and Roberts model is very short in the tested conditions, was practically nonexistent at $4{ }^{\circ} \mathrm{C}$ and pH 6.0 and 6.3 and at $12^{\circ} \mathrm{C}$ and pH 5.5. With regard to the maximum specific growth rate, it presents, at $\mathrm{pH} 6.0$, higher value as much as $4{ }^{\circ} \mathrm{C}$ to $7^{\circ} \mathrm{C}$, confirmed by both models applied. This faster growth at $\mathrm{pH} 6.0$ is notable when comparing the population level reached by $B$. thermosphacta. For example, concentration around $10^{6} \mathrm{CFU} / \mathrm{mL}$, order in which the deteriorative signs begin to emerge, is reached in about 50 hours at $4{ }^{\circ} \mathrm{C}$ and $\mathrm{pH} 6.0$, while in other conditions, $\mathrm{pH} 5.5$ and 6.3, this concentration is reached only about 70 hours. Therefore, it can be inferred that meat pH 5.5 or 6.3 , stored at $4{ }^{\circ} \mathrm{C}$, is preserved better than at pH 6.0. How we can see in Figure 1 bellow.

The fact that the growth of $B$. thermosphacta provide short lag phase in all tested conditions was probably due to the culture activation step prior to inoculation into broth.

Table 1. Growth parameters observed for B. thermosphacta in meat broth at $4{ }^{\circ} \mathrm{C}, 7^{\circ} \mathrm{C}$ and $12^{\circ} \mathrm{C}$ and $\mathrm{pH}$ 5.5, 6.0 and 6.3.

\begin{tabular}{cccccc}
\hline Growing & \multicolumn{3}{c}{ Baranyi e Roberts } & & \multicolumn{2}{c}{ Gompertz } \\
\cline { 2 - 3 } \cline { 5 - 6 } conditions & $\lambda(\mathrm{h})$ & $\mu_{\max }\left(\mathrm{h}^{-1}\right)$ & & $\lambda(\mathrm{h})$ & $\mu_{\max }\left(\mathrm{h}^{-1}\right)$ \\
\hline $4^{\circ} \mathrm{C}$ and pH 5.5 & 4.85 & 0.036423 & & - & 0.029839 \\
$4^{\circ} \mathrm{C}$ and pH 6.0 & $3.24 \mathrm{E}-07$ & 0.048561 & & - & 0.042477 \\
$4{ }^{\circ} \mathrm{C}$ and pH 6.3 & $1.86 \mathrm{E}-07$ & 0.043232 & & - & 0.035897 \\
$77^{\circ} \mathrm{C}$ and pH 5.5 & 13.29 & 0.065708 & & 11,87 & 0.060474 \\
$77^{\circ} \mathrm{C}$ and pH 6.0 & 10.05 & 0.078342 & & 8,26 & 0.070011 \\
$77^{\circ} \mathrm{C}$ and pH 6.3 & 6.38 & 0.073423 & & - & 0.060197 \\
$12^{\circ} \mathrm{C}$ and pH 5.5 & $1.41 \mathrm{E}-06$ & 0.092588 & & - & 0.076627 \\
$12^{\circ} \mathrm{C}$ and pH 6.0 & 2.63 & 0.10998 & & - & 0.090355 \\
$12^{\circ} \mathrm{C}$ and pH 6.3 & 1.59 & 0.112014 & & - & 0.093117 \\
\hline
\end{tabular}

$\lambda$ : duration of lag phase; $\mu_{\text {max: }}$ maximum specific growth rate.

Table 2. $\mathrm{R}^{2}$ and RMSE of primary growth model for B. thermosphacta.

\begin{tabular}{ccccccc}
\hline \multirow{2}{*}{$\begin{array}{c}\text { Growing } \\
\text { conditions }\end{array}$} & \multicolumn{2}{c}{ Baranyi and Roberts } & & \multicolumn{2}{c}{ Gompertz } \\
\cline { 2 - 3 } \cline { 5 - 6 } \cline { 5 - 6 } & $\mathrm{R}^{2}$ & RMSE & & $\mathrm{R}^{2}$ & RMSE \\
\hline $4{ }^{\circ} \mathrm{C}$ and pH 5.5 & 0.99 & 0.1682 & & 0.99 & 0.1764 \\
$4{ }^{\circ} \mathrm{C}$ and pH 6.0 & 0.98 & 0.1444 & & 0.98 & 0.1453 \\
$4{ }^{\circ} \mathrm{C}$ and pH 6.3 & 0.98 & 0.1341 & & 0.98 & 0.1348 \\
$7{ }^{\circ} \mathrm{C}$ and pH 5.5 & 0.994 & 0.1149 & & 0.992 & 0.1356 \\
$7{ }^{\circ} \mathrm{C}$ and pH 6.0 & 0.993 & 0.1335 & & 0.996 & 0.1047 \\
$7{ }^{\circ} \mathrm{C}$ and pH 6.3 & 0.996 & 0.1065 & & 0.995 & 0.1144 \\
$12{ }^{\circ} \mathrm{C}$ and pH 5.5 & 0.993 & 0.1267 & & 0.993 & 0.1267 \\
$12{ }^{\circ} \mathrm{C}$ and pH 6.0 & 0.995 & 0.1099 & & 0.996 & 0.0958 \\
$12{ }^{\circ} \mathrm{C}$ and pH 6.3 & 0.98 & 0.1600 & & 0.992 & 0.1358 \\
\hline
\end{tabular}

Note also, at $7{ }^{\circ} \mathrm{C}$, a decrease in the duration of the lag phase of 13.28 hours to 6.28 hours, as the $\mathrm{pH}$ becomes more near neutrality (Table 1; Figure 2). As the $\mu_{\max }$ parameter, as had already occurred at $4{ }^{\circ} \mathrm{C}$, the highest value was found at $\mathrm{pH}$ 6.0. Generally, the $\mathrm{pH}$ closer the $\mathrm{pH}$ neutral, faster will be microbial growth. Leroi et al. (2012) highlight in their work the neutral $\mathrm{pH}$ was great for the growth of $B$. thermosphacta, but its development was possible even in $\mathrm{pH}$ 4.8. Corroborating Gribble et al. (2014) which points out that under aerobic conditions $B$. thermosphacta is able to grow at low $\mathrm{pH}$. The Figure 2 bellow shows the prediction curves at $12{ }^{\circ} \mathrm{C}$.

The analysis of the growth parameters at $12{ }^{\circ} \mathrm{C}$, shows the lag phase, estimated only by the Baranyi and Roberts model, very short, particularly in $\mathrm{pH} 5.5$ and $\mu$ max increased as the $\mathrm{pH}$ rises. The Figure 3 shows the prediction curves at $12{ }^{\circ} \mathrm{C}$.

Table 3. Baranyi and Roberts and modified Gompertz growth models for P. fluorescens at $4{ }^{\circ} \mathrm{C}, 7^{\circ} \mathrm{C}$ and $12{ }^{\circ} \mathrm{C}$, and $\mathrm{pH} 5.5,6.0$, and 6.3.

\begin{tabular}{|c|c|c|}
\hline Model & $\begin{array}{l}\text { Growing } \\
\text { conditions }\end{array}$ & Equation \\
\hline \multirow{3}{*}{$\begin{array}{l}\text { Baranyi and } \\
\text { Roberts }\end{array}$} & $4^{\circ} \mathrm{C}$ and $\mathrm{pH} 5.5$ & $\begin{array}{c}\mathrm{dN} / \mathrm{dt}=-1.1932043 \times 0.036423 \mathrm{x} \\
{[1-\mathrm{N}(\mathrm{t}) / 7.149077] \mathrm{xN}(\mathrm{t})}\end{array}$ \\
\hline & $4^{\circ} \mathrm{C}$ and $\mathrm{pH} 6.0$ & $\begin{array}{c}\mathrm{dN} / \mathrm{dt}=-1 \mathrm{x} 0.048561 \mathrm{x} \\
{[1-\mathrm{N}(\mathrm{t}) / 7.701309] \mathrm{xN}(\mathrm{t})}\end{array}$ \\
\hline & $4^{\circ} \mathrm{C}$ and $\mathrm{pH} 6.3$ & $\begin{array}{c}\mathrm{dN} / \mathrm{dt}=-1 \mathrm{x} 0.043232 \mathrm{x} \\
{[1-\mathrm{N}(\mathrm{t}) / 7.924358] \mathrm{xN}(\mathrm{t})}\end{array}$ \\
\hline \multirow{3}{*}{ Gompertz } & $4^{\circ} \mathrm{C}$ and $\mathrm{pH} 5.5$ & $\begin{array}{c}\operatorname{LogN}(\mathrm{t})=3.838248+ \\
3.49116117 \exp \{-\exp \\
[-0.023233(\mathrm{t}-43.04189)]\}\end{array}$ \\
\hline & $4^{\circ} \mathrm{C}$ and $\mathrm{pH} 6.0$ & $\begin{array}{c}\operatorname{LogN}(t)=3.810863+3.81597145 \exp \\
\quad\{-\exp [-0.030258(t-33.04901)]]\end{array}$ \\
\hline & $4^{\circ} \mathrm{C}$ and $\mathrm{pH} 6.3$ & $\begin{array}{c}\operatorname{LogN}(t)=3.977424+4.19993083 \exp \\
\quad\{-\exp [-0.02323(t-43.04189)]\}\end{array}$ \\
\hline \multirow{3}{*}{$\begin{array}{l}\text { Baranyi and } \\
\text { Roberts }\end{array}$} & $7^{\circ} \mathrm{C}$ and $\mathrm{pH} 5.5$ & $\begin{array}{c}\mathrm{dN} / \mathrm{dt}=2.3944289 \mathrm{x} 0.065708 \mathrm{x} \\
{[1 \mathrm{~N}(\mathrm{t}) / 7.978267] \mathrm{xN}(\mathrm{t})}\end{array}$ \\
\hline & $7^{\circ} \mathrm{C}$ and $\mathrm{pH} 6.0$ & $\begin{array}{c}\mathrm{dN} / \mathrm{dt}=2.3944389 \mathrm{x} 0.078342 \mathrm{x} \\
{[1 \mathrm{~N}(\mathrm{t}) / 8.258502] \mathrm{xN}(\mathrm{t})}\end{array}$ \\
\hline & $7^{\circ} \mathrm{C}$ and $\mathrm{pH} 6.3$ & $\begin{array}{c}\mathrm{dN} / \mathrm{dt}=1.5980269 \mathrm{x} 0.073423 \mathrm{x} \\
{[1 \mathrm{~N}(\mathrm{t}) / 8.353738] \mathrm{xN}(\mathrm{t})}\end{array}$ \\
\hline \multirow{3}{*}{ Gompertz } & $7^{\circ} \mathrm{C}$ and $\mathrm{pH} 5.5$ & $\begin{array}{c}\log N(t)=4.137266+3.70408461 \exp \\
\quad\{-\exp [0.044379(t-34.40365)]\}\end{array}$ \\
\hline & $7^{\circ} \mathrm{C}$ and $\mathrm{pH} 6.0$ & $\begin{array}{c}\operatorname{LogN}(t)=4.074842+4.05749568 \exp \\
\quad\{-\exp [0.046903(t-29.58479)]\}\end{array}$ \\
\hline & $7^{\circ} \mathrm{C}$ and $\mathrm{pH} 6.3$ & $\begin{array}{c}\log N(t)=4.063964+4.17958697 \exp \\
\quad\{-\exp [0.039151(t-25.54234)]\}\end{array}$ \\
\hline \multirow{3}{*}{$\begin{array}{l}\text { Baranyi and } \\
\text { Roberts }\end{array}$} & $12^{\circ} \mathrm{C}$ and $\mathrm{pH} 5.5$ & $\begin{array}{c}\mathrm{dN} / \mathrm{dt}=1.0000001 \mathrm{x} 0.092588 \mathrm{x} \\
{[1 \mathrm{~N}(\mathrm{t}) / 8.332531] \mathrm{xN}(\mathrm{t})}\end{array}$ \\
\hline & $12{ }^{\circ} \mathrm{C}$ and $\mathrm{pH} 6.0$ & $\begin{array}{c}\mathrm{dN} / \mathrm{dt}=-1.3350782 \mathrm{x} 0.10998 \mathrm{x} \\
{[1-\mathrm{N}(\mathrm{t}) / 8.491625] \mathrm{xN}(\mathrm{t})}\end{array}$ \\
\hline & $12^{\circ} \mathrm{C}$ and $\mathrm{pH} 6.3$ & $\begin{array}{c}\mathrm{dN} / \mathrm{dt}=-1.195696 \mathrm{x} 0.112014 \mathrm{x} \\
{[1-\mathrm{N}(\mathrm{t}) / 8.472856] \mathrm{xN}(\mathrm{t})}\end{array}$ \\
\hline \multirow{3}{*}{ Gompertz } & $12^{\circ} \mathrm{C}$ and $\mathrm{pH} 5.5$ & $\begin{array}{c}\operatorname{LogN}(t)=4.30574+3.93048849 \exp \\
\{-\exp [-0.052994(t-18.86998)]\}\end{array}$ \\
\hline & $12^{\circ} \mathrm{C}$ and $\mathrm{pH} 6.0$ & $\begin{array}{c}\operatorname{LogN}(t)=4.448302+3.96353344 \exp \\
\quad\{-\exp [0.061968(t-16.13748)]\}\end{array}$ \\
\hline & $12^{\circ} \mathrm{C}$ and $\mathrm{pH} 6.3$ & $\begin{array}{c}\operatorname{LogN}(t)=4.510883+3.88615589 \exp \\
\{-\exp [0.065133(t-15.35312)]\end{array}$ \\
\hline
\end{tabular}



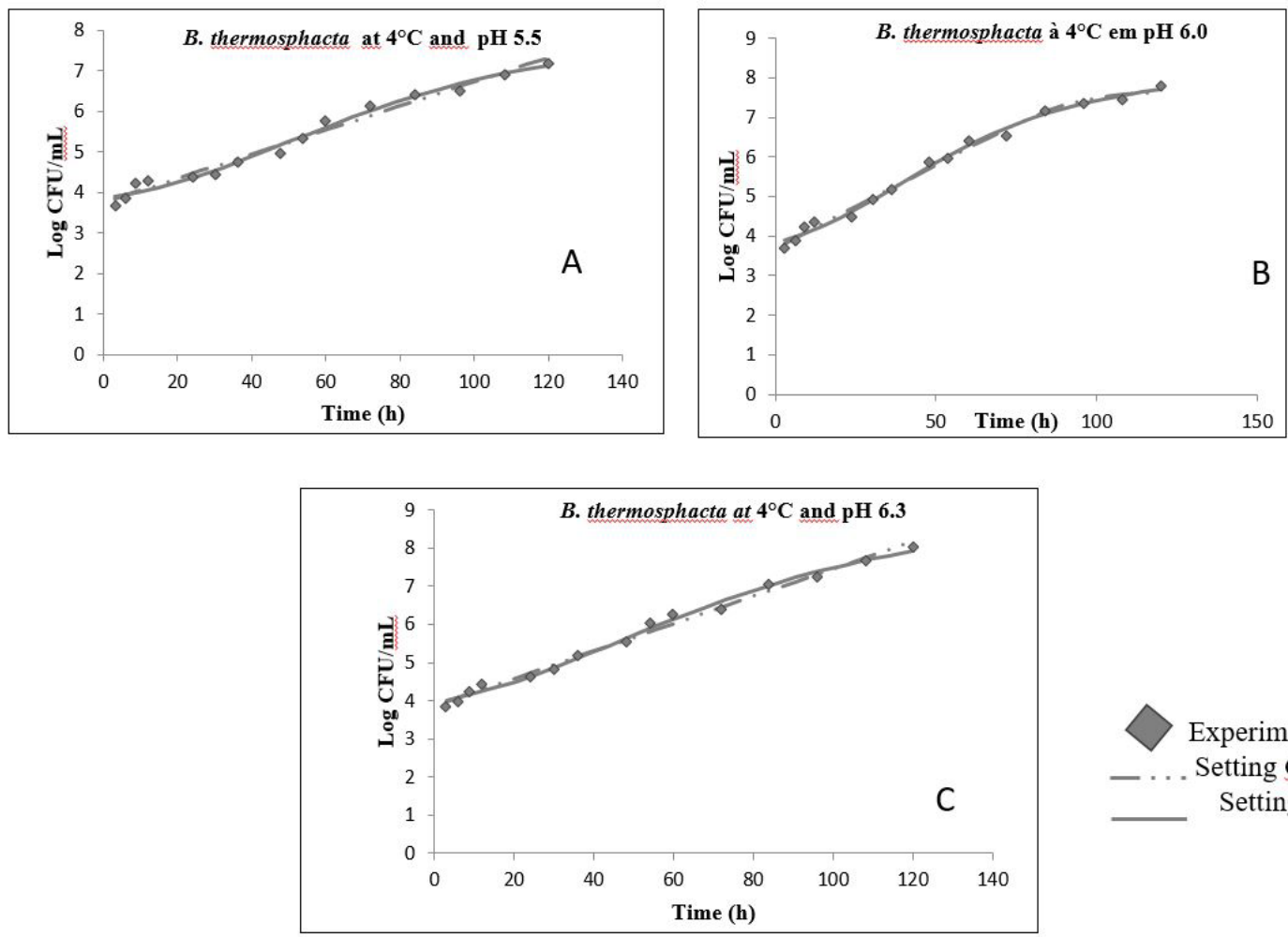

Experimental data

Setting Gompertz

Setting Baranyi

Figure 1. Primary growth modeling of $B$. thermosphacta at $4{ }^{\circ} \mathrm{C}$ and $\mathrm{pH} 5.5(\mathrm{~A}), \mathrm{pH} 6.0(\mathrm{~B})$ and $\mathrm{pH} 6.3(\mathrm{C})$.

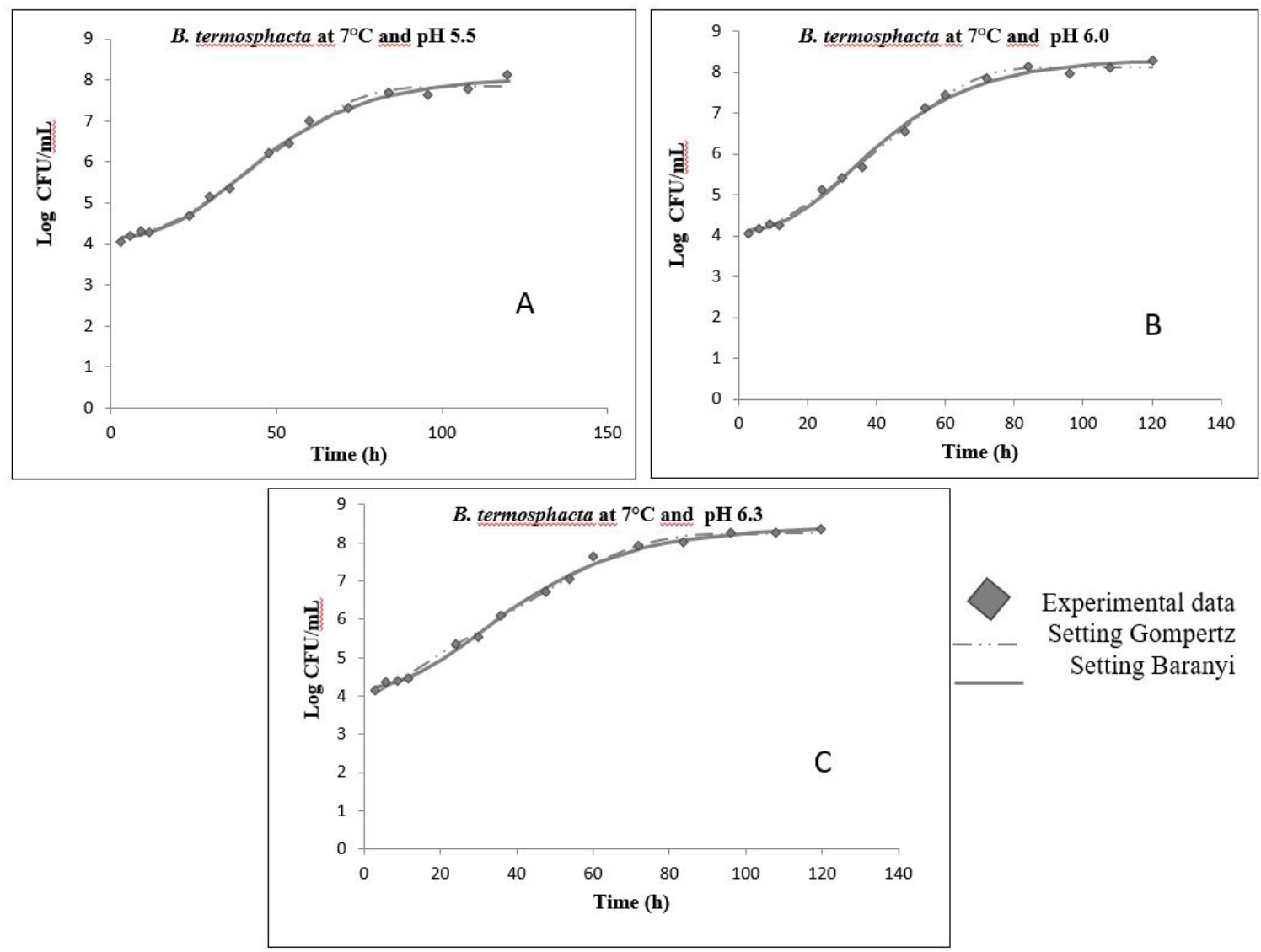

Figure 2. Primary growth model of $P$. fluorescens at $7{ }^{\circ} \mathrm{C}$ and $\mathrm{pH} 5.5$ (A), pH 6.0 (B) and pH 6.3 (C). 

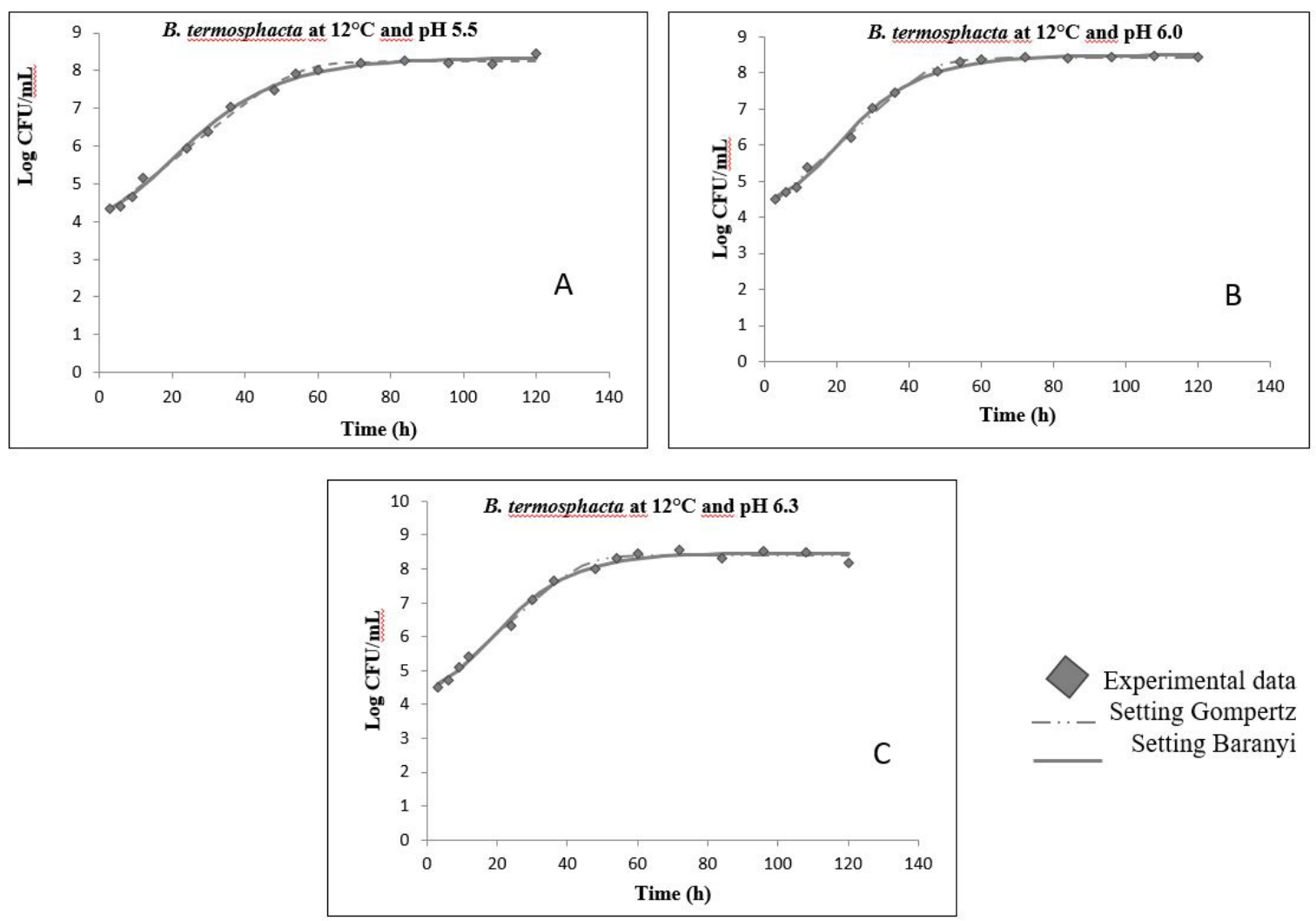

Figure 3. Primary growth model of P. fluorescens at $12{ }^{\circ} \mathrm{C}$ and $\mathrm{pH} 5.5$ (A), $\mathrm{pH} 6.0$ (B) and pH 6.3 (C).

By analyzing the behavior of $B$. thermosphacta in relation to the temperature rise of $7{ }^{\circ} \mathrm{C}$ (ideal for cooling) to $12{ }^{\circ} \mathrm{C}$ (temperature abuse), it is observed considerable reduction of lag phase of $13.28 \mathrm{~h} ; 10.05 \mathrm{~h}$ and $6.38 \mathrm{~h}$ to $1.41^{\star} 10^{-6} \mathrm{~h} ; 2.36 \mathrm{~h}$ and $1.59 \mathrm{~h}$, at $\mathrm{pH} 5.5 ; 6.0$ and 6.3 respectively. It is also noted an increase in the maximum specific growth rate of $0.065708 \mathrm{~h}^{-1}$, $0.078342 \mathrm{~h}^{-1}$ and $0.073423 \mathrm{~h}^{-1}$, at pH 5.5; 6.0 and 6.3, respectively, by the Baranyi and Roberts model, to $0.092588 \mathrm{~h}^{-1}, 0.10998 \mathrm{~h}^{-1}$ and $0.112014 \mathrm{~h}^{-1}$, respectively and $0.060474 \mathrm{~h}^{-1}, 0.070011 \mathrm{~h}^{-1}$ and $0.060197 \mathrm{~h}^{-1}$, at pH 5.5; 6.0 and 6.3, respectively, by modified Gompertz model to $0.076627 \mathrm{~h}^{-1}, 0.090355 \mathrm{~h}^{-1}$ and $0.093117 \mathrm{~h}^{-1}$, respectively. The comparison of predicted values for $\mu$ max, when the temperature exceeds $4{ }^{\circ} \mathrm{C}$, ideal for cooling, to $12^{\circ} \mathrm{C}$, abuse temperature, it is clear that these rates more than double. It is emphasized, therefore, the importance of using low temperatures to delay the onset of changes that occur in the meat due the development of spoilage bacteria (Ercolini et al., 2009).

The comparison of all growth conditions applied to B. thermosphacta shows that as the temperature is high $\mu$ max also raises, and that $\mathrm{pH}$ increase resulted in increased $\mu$ max only at $12{ }^{\circ} \mathrm{C}$, since in the other tested temperatures, it was noted that growth in the intermediate $\mathrm{pH}$ tested (6.0) showed higher $\mu \mathrm{max}$ and the $\mathrm{pH}$ increase also resulted in a decrease in $\lambda$, in two temperature conditions $\left(4^{\circ} \mathrm{C}\right.$ and $\left.7^{\circ} \mathrm{C}\right)$.

Regarding $\lambda$, there was no direct correlation between $\mathrm{pH}$ and temperature for this parameter. It is only noted that the increase of $4{ }^{\circ} \mathrm{C}$ to $7^{\circ} \mathrm{C}$ led to increase in length of the lag phase of $4.85 \mathrm{~h} 3.24^{\star} 10^{-7} \mathrm{~h}$ and $1.86^{\star} 10^{-7} \mathrm{~h}$ at $\mathrm{pH} 5.5 ; 6.0$ and 6.3 , to $13.29 \mathrm{~h}, 10.05 \mathrm{~h}$ and $6.38 \mathrm{~h}$ respectively, while the rise in $\mathrm{pH}$ at each of these temperatures to the reduction of lag phase as $\mathrm{pH}$ approaches neutrality.

It can be said that the $\lambda$ and $\mu$ max values estimated by the primary growth models are considered valid, since, for all growing conditions and for the two tested models showed $\mathrm{R}^{2}$ very close to 1 and RMSE near zero (Table 2). This means that the curves of Baranyi and Roberts and modified Gompertz adjusted well to the experimental data and the predicted values are close to those observed. In general, the Baranyi and Roberts model showed slightly better fit to the experimental data.

Once validated, the obtained primary equations (Table 3 ) can be used to predict $B$. thermosphacta growth in meat broth, in the same conditions tested.

\subsection{Secondary growth model of $B$. thermosphacta in meat broth}

Table 4 shows the secondary models generated for the effect of temperature and $\mathrm{pH}$ on the maximum specific growth rate and statistical parameters for validate, coefficient of determination $\left(\mathrm{R}^{2}\right)$, the root mean square error (RMSE), the bias factor and the accuracy factor, to validate the growth models of $B$. thermosphacta in broth

By means of the equations generated by this modeling (Table 4) can be varied combinations of temperature and 
Table 4. Secondary models for B. thermosphacta and statistical parameters for validate.

\begin{tabular}{llcccc}
\hline \multicolumn{1}{c}{ Primary model } & Secundary model of the square root & $\mathrm{R}^{2}$ & EQM & Bias factor & Accuracy factor \\
\hline Baranyi and Roberts & $\mu_{\max }=4.61577^{\star} 10^{-5}[(\mathrm{~T}-10.977245)]^{2} \mathrm{x}(\mathrm{pH}-1.5099520)$ & 0.9323 & 0.0136 & 0.9982 & 1.3845 \\
Gompertz & $\mu_{\max }=0.0000367[(\mathrm{~T}-(-11.7047))] 2 \mathrm{x}(\mathrm{pH}-1.567511)$ & 0.8630 & 0.0175 & 0.9971 & 1.0799 \\
\hline
\end{tabular}

$\mathrm{pH}$ values and estimate the maximum specific rate at which B. thermosphacta grow in broth or meat or fresh meat, since the meat broth simulates the nutritional requirements for fresh meat. For example, meat with an initial $\mathrm{pH}$ of 5.6 and stored at $4{ }^{\circ} \mathrm{C}$, by Baranyi and Roberts model, present $\mu$ max of $0.04234 \mathrm{~h}^{-1}$. Already meat with an initial $\mathrm{pH}$ of 6.2 and stored at $9^{\circ} \mathrm{C}$ present $\mu$ max of $0.08639 \mathrm{~h}^{-1}$. Note, through these values, that the increase of $\mathrm{pH}$ and temperature cause greatly impacts in the $\mu$ max lifting. This same relationship was observed by Koutsoumanis et al. (2006) in a study with fresh ground beef with $\mathrm{pH}$ ranging between 5.34 and 6.13 and stored at different temperatures $\left(0-20^{\circ} \mathrm{C}\right)$. Similarly Leroi et al. (2012) in a study with different strains of $\mathrm{B}$. thermosphacta observed increase in $\mu$ max. with the temperature rise $\left(10-35^{\circ} \mathrm{C}\right)$ and also with increasing $\mathrm{pH} 4.8$ to around 7.0 , above this value was noted to drop in $\mu$ max.

By analyzing the statistical parameters, the two models can be considered validate, but overall the secondary model generated from the primary model of Baranyi and Roberts presents better fit of Ratkowsky model to experimental data, shows slight advantage as the validation of the generated secondary equations

\section{Conclusion}

The modeling of the growth of $B$. thermosphacta in meat broth showed good agreement of the curves of the primary models to experimental data and low deviation between observed and predicted values, which can then be used to predict the growth of $B$. thermosphacta under the same conditions tested. It was noted that the $\mathrm{pH}$ changes did not impact much on growth parameters such as temperature changes.

Finally, the secondary models generated showed good statistical indices ( $\mathrm{R}^{2}$, RMSE, bias factor and factor accuracy) for both primary models that generated them, which makes them validated to estimate $\mu$ max of $B$. thermosphacta, when the temperature and $\mathrm{pH}$ varies.

\section{Acknowledgements}

The authors thank the CAPES for granting master's scholarship, the Federal University of Lavras and the Mitah Technologies for the encouragement and facilitation of executing the study.

\section{References}

AL-Jasser M. S. (2012). Effect of cooling and freezing temperatures on microbial and chemical properties of chicken meat during storage. Journal of Food, Agriculture \& Environment, 10(1), 113-116.

Cárdenas, F. C., Giannuzzi, L., \& Zaritzky, N. E. (2008). Mathematical modelling of microbial growth in ground beef from Argentina. Effect of lactic acid addition, temperature and packaging film. Meat Science, 79(3), 509-520. http://dx.doi.org/10.1016/j.meatsci.2007.12.003. PMid:22062911.
Casaburi, A., Filippis, D. E. F., Villani, F., \& Ercolini, D. (2014). Activities of strains of Brochothrix thermosphacta in vitro and in meat. Food Research International, 62, 366-374. http://dx.doi.org/10.1016/j. foodres.2014.03.019.

Couvert, O., Pinon, A., Bergis, H., Bourdichon, F., Carlin, F., Cornu, M., Denis, C., Gnanou Besse, N., Guillier, L., Jamet, E., Mettler, E., Stahl, V., Thuault, D., Zuliani, V., \& Augustin, J. C. (2010). Validation of a stochastic modelling approach for Listeria monocytogenes growth in refrigerated foods. International Journal of Food Microbiology, 144(2), 236-242. http://dx.doi.org/10.1016/j.ijfoodmicro.2010.09.024. PMid:21035224.

Dainty, R. H., \& Mackey, B. M. (1992). The relationship between the phenotypic properties of bacteria form chill-stored meat and spoilage processes. Journal of Applied Bacteriology, 73(21), 103S-114S.

Ercolini, D., Russo, F., Nasi, A., Ferranti, P., \& Villani, F. (2009). Mesophilic and Psychrotrophic bacteria from meat and their spoilage potential in vitro and in beef. Applied and Environmental Microbiology, 75(7), 1990-2001. http://dx.doi.org/10.1128/AEM.02762-08.

Franco, B. D. G. M., \& Landgraf, M. (2005). Microbiologia dos alimentos (196 p.). São Paulo: Atheneu.

Gribble, A., Mills, J., \& Brightwell, G. (2014). The spoilage characteristics of Brochothrix thermosphacta and two psychrotolerant Enterobacteriacae in vacuum packed lamb and the comparison between high and low pH cuts. Meat Science, 97(1), 83-92. http://dx.doi.org/10.1016/j. meatsci.2014.01.006. PMid:24548927.

Hernández-Macedo, M. L., Barancelli, G. V., \& Contreras-Castillo, C. J. (2011). Microbial deterioration of vacuum-packaged chilled beef cuts and techniques for microbiota detection and characterization: a review. Brazilian Journal of Microbiology, 42(1), 1-11. http://dx.doi. org/10.1590/S1517-83822011000100001. PMid:24031598.

Juneja, V. K., Marks, H. M., \& Huang, L. (2003). Growth and heat resistance kinetic variation among various isolates of Salmonella and its application to risk assessment. Risk Analysis, 23(1), 199-213.

Koutsoumanis, K., Stamatiou, A., Skandamis, P., \& Nychas, G. J. E. (2006). Development of a microbial model for the combined effect of temperature and $\mathrm{pH}$ on spoilage of ground meat, and validation of the model under dynamic temperature conditions. Applied and Environmental Microbiology, 72(1), 124-134. http://dx.doi.org/10.1128/ AEM.72.1.124-134.2006.

Leroi, F., Fall, P. A., Pilet, M. F., Chevalier, F., Baron, R. (2012). Influence of temperature, $\mathrm{pH}$ and $\mathrm{NaCl}$ concentration on the maximal growth rate of Brochothrix thermosphacta and a bioprotective bacteria Lactococcus piscium CNCM I-4031. Food Microbiology, 31(2), 222228.http://dx.doi.org/10.1016/j.fm.2012.02.014.

Madigan, M. T., Martinko, J. M., Dunlap, P. V., \& Clark, D. P. (2010). Microbiologia de Brock. Porto Alegre: Artmed.

Nowak, A., \& Piotrowska, M. (2012). Biochemical activities of Brochothrix thermosphacta. Meat Science, 90(2), 410-413. http:// dx.doi.org/10.1016/j.meatsci.2011.08.008. PMid:21914560.

Nychas, G. J. E., Skandamis, P. N., Tassou, C. C., \& Koutsoumanis, K. P. (2008). Meat spoilage during distribution. Meat Science, 78(1-2), 7789. http://dx.doi.org/10.1016/j.meatsci.2007.06.020. PMid:22062098.

Pin, C., García De Fernando, G. D., \& Ordóñez, J. A. (2002). Effect of modified atmosphere composition on the metabolism of glucose by 
Brochothrix thermosphacta. Applied and Environmental Microbiology, 68(9), 4441-4447.

Russo, F., Ercolini, D., Mauriello, G., \& Villani, F. (2006). Behaviour of Brochothrix thermosphacta in presence of other meat spoilage microbial groups. Food Microbiology, 23(8), 797-802. http://dx.doi. org/10.1016/j.fm.2006.02.004. PMid:16943085.

Samapundo, S., Devlieghere, F., Meulenaer, B., Geeraerd, A. H., Van Impe, J. F., \& Debevre, J. M. (2005). Predictive modelling of the individual and combined effect of water activity and temperature on the radial growth of Fusarium verticilliodes and F. proliferatum on corn. International Journal of Food Microbiology, 105(1), 35-52.

Zhou, K., Fu, P., Li, P., Cheng, W., \& Liang, Z. (2009). Predictive modeling and validation of growth at different temperatures of Brochothrix thermosphacta. Journal of Food Safety, 29(3), 460-473. http://dx.doi. org/10.1111/j.1745-4565.2009.00169.x. 